$\begin{aligned} & \text { Mars mission } \\ & \text { Full conversion to } \\ & \text { metric system might } \\ & \text { have saved Orbiter' } \\ & 0517\end{aligned}$
$\begin{aligned} & \text { Heredity was the } \\ & \text { dominant theme at } \\ & \text { this year's awards } \\ & p 518\end{aligned}$

\title{
Terms of access to cloned mice comes under researchers' fire
}

\section{San Diego}

A powerful 'gene-trapping' technology, first described in a paper published in Nature last year, has become the focus of a battle for access to proprietary molecular tools, with academic researchers pitted against the company that owns the technology.

The dispute, which sets researchers from universities and the Howard Hughes Medical Institute (HHMI) against the privately owned Lexicon Genetics of Texas, has highlighted a growing source of tension between the academic world and corporate interests. Academics want reasonable access to discoveries published in the scientific literature, while companies such as Lexicon seek to profit from their proprietary technology.

Some academics say the case illustrates the need for stricter rules to make researchers - whether from academia or industry who publish in the open literature provide reagents and molecular tools to non-commercial investigators without restrictive provisions in material-transfer agreements.

In April 1998, six scientists from Lexicon published an article (Nature 392, 608-611; 1998) describing a high-throughput mutagenesis method in which 'gene trapping' provides an automated way of identifying sequence tags from mutated genes.

The Lexicon scientists reported that they were creating a library of mouse embryonic stem cells, called Omnibank. They noted that sequence-tagged mutations in 2,000 genes had initially been placed in Omnibank. The library now includes around 70,000 mouse genetic clones. The paper concluded: "Lexicon will distribute the [embryonic stem] cell clones described here to requesting investigators for non-commercial research."

But when Lawrence S. B. Goldstein, an HHMI geneticist at the University of California at San Diego, tried to obtain a particular mutated embryonic stem cell line last summer, he ran into what he termed "onerous" terms that became a "roadblock" to receiving the cell line. Lexicon sought at least $\$ 15,000$ for the stem cells, Goldstein says, as well as 'reach-through rights' to any commercial product from his use of the cells.

Pointing out that he believed his planned

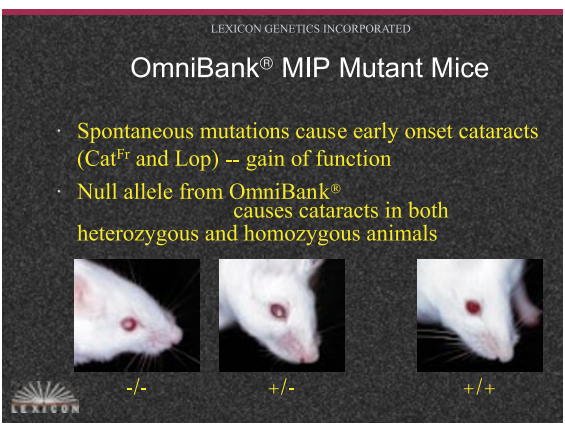

Mouse trap? Some scientists claim Lexicon's embryonic stem-cell library has 'excessive' costs.

experiments "had no commercial value", Goldstein describes Lexicon's open publication of the technique and subsequent restrictions as a type of "shell game" in which the company used the journal for "an advertisement". Goldstein says he has no objections to a company placing tough restrictions on its unpublished materials. But he adds: "If you aren't going to send materials out, don't publish and take the credit."

Michael Green, a HHMI molecular biologist at the University of Massachusetts
Medical School at Worcester, said he had a similar experience when asking Lexicon for a retroviral vector referenced in the same paper. After his inquiries to the company had gone unanswered, he says, he obtained a response from Lexicon only by enlisting the assistance of a Nature editor.

But Lexicon then set restrictions on the transfer of the vector that neither HHMI nor his university would agree to, says Green. After months of delays, he finally received an ill-defined description of the sequence for the vector. But because of the insufficient quality of the sequence description and the delay, Green reluctantly used another vector obtained from an academic researcher.

Arthur Sands, the chief executive and a founder of Lexicon, denies that his company has violated Nature's policy on sharing materials. A physician with a $\mathrm{PhD}$ in molecular biology, and a co-author of the paper, he says the company "operates in good faith" and has "very liberal agreements" on sharing resources. "We have distributed clones from the publication very broadly," he says.

Sands attributes Goldstein's difficulties to a "misunderstanding" and "confusion"

\section{UK marine centres face job losses}

\section{London}

Forty-nine research and technical jobs are to be lost at Britain's Centre for Coastal and Marine Sciences (CCMS), because of what its core funding agency, the Natural Environment Research Council (NERC), describes as "severe financial difficulties".

Twenty-seven redundancies will be compulsory. Most will come from the Plymouth Marine Laboratory, and four from the Proudman Oceanographic Laboratory.

The redundancies have been blamed on declining support from government and industry. Over the past three to four years, CCMS has seen a 30 per cent decline in government contracts and a deterioration in support for long-term research.
The Institute of Professionals, Managers and Specialists - the union that represents many research council scientists - has expressed concern over the job losses.

But it welcomed a $\mathfrak{E 7}$ million (US\$11.6 million) rescue plan from NERC. This will cover the centre's deficits from the past two years, and the estimated cost of the redundancies.

NERC has approved a package that cancels an extension to the Plymouth Marine Laboratory and privatizes some of its work. After a review of CCMS science programmes, it has been decided that redundancies will occur in the research areas of lipid membranes, larval fish biology, numerical modelling and southern ocean dynamics.

Natasha Loder 
regarding material-transfer agreements, although when contacted by Nature he said he was unaware of Green's claimed difficulties. Sands says that he subsequently contacted Goldstein to try to "clear up any misunderstanding", but at the time of going to press Goldstein said he had not received the material.

Sands says that, since the publication of the paper, his company has transferred materials to 41 non-commercial investigators at 27 institutions. He declined to provide a list of the investigators, but named half a dozen researchers at four universities. Interviews with some of these showed a substantial fee was paid for unpublished material, while one institution was asked to cede reach-through rights to Lexicon.

These concerns prompted HHMI officials to circulate a memorandum to its 300 researchers. HHMI spokesman Robert Potter issued a statement: "Several HHMI investigators have expressed interest in

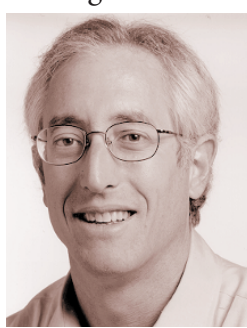
having access to Omnibank and related resources owned by Lexicon for their research. So far, we have been unable to come to terms on an arrangement for such Goldstein: faced with access."

“onerous" terms.

To researchers, the conflict shows that enforcement is needed to make material from the published domain more readily available. Such problems remain, says Green, because "no one wants to take responsibility for the enforcement".

Green argues that the National Institutes of Health, which last spring issued suggested guidelines for making materials available from its own funded research (see Nature 399, 291; 1999), should take a greater responsibility for the situation. NIH director Harold Varmus, a champion of ready access to published research materials, was unavailable for comment.

Several scientists said major journals that have policies on access to materials from published research should prohibit authors from publishing if they break the rules on material transfers. Rex Dalton

Nature's policy is that materials should be made freely available. This is made explicitly clear to all authors as a condition of publication. Where the conditions are subsequently broken, Nature reserves the right, as one possible sanction, to refuse to consider further papers from the authors or even, where necessary, the institution or company concerned. We are contacting the authors at Lexicon and will inform readers of the outcome. The editor

\section{Company to use advertising to cover Pubmed Central costs}

\section{Baltimore}

A private company that provides researchers with information about funding opportunities and other activities announced last week that it will provide 'front end' services on Pubmed Central, the free repository for research results which the National Institutes of Health (NIH) plans to launch in January.

These services will enable societies and individuals to publish peer-reviewed research and are to be provided by Community of Science (COS), based in Baltimore, which keeps profiles of 500,000 researchers globally.

Huntington Williams, COS's president said his company was trying to formulate an economic model for publishing on Pubmed Central. The costs of processing and reviewing manuscripts would be covered by online advertising and direct marketing aimed at the scientists who select the reviewers and the reviewers themselves.

COS is the first organization to propose a business model that would allow electronic journals which publish on Pubmed Central - and therefore have no subscription revenue - to cover the costs of arranging for the review of scientific papers, and editing the text and illustrations into a standard format ready for publication.

These costs would be covered by selling web advertising and web marketing targeted at the reviewers themselves and at the boards of researchers that select them. The existing COS database would enable such advertising and marketing to be tightly targeted at these scientists' interests and personal habits.

Williams refused to speculate over how much money could be raised in this way, but

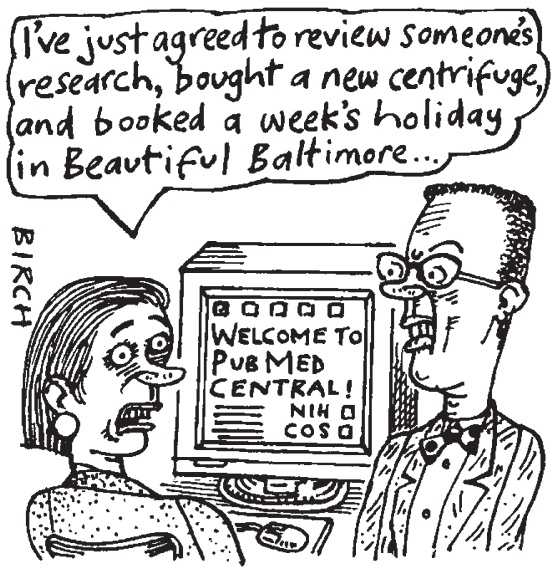

the newsletter Science and Government Report quotes COS officials as saying that, while unspecified journals spend $\$ 4000$ to process each paper, the new system might do it for $\$ 250$. The model assumes that this amount, plus profit, could be generated by advertising and marketing aimed at referees.

Williams said the model would enable COS subscribers, as well as societies who wanted to publish their journals on Pubmed Central, to publish results in the new repository. COS and the societies would revenues from the advertising and marketing, he said.

David Lipman, director of the National Center for Biotechnology Information at the $\mathrm{NIH}$ and one of the architects of Pubmed Central, said that COS's plans were one of "a wide variety of business models" which the repository would accommodate. $\mathrm{He}$ adds that plans for PubMed Central's launch are focusing mainly on the part incorporating peer-reviewed content.

Colin Macilwain

\section{Optical society vote sees off merger}

San Diego

Members of the Optical Society of America (OSA) voted last week not to merge with the International Society for Optical Engineering (SPIE), ending months of contentious campaigning at the two societies.

The result was announced last week at the society's annual meeting in Santa Clara, California. SPIE had voted by mail earlier in the summer, with the result to be announced on Tuesday of this week. But the response from the OSA membership kills the merger, which was first mooted in early 1998.

OSA's leadership had sought the merger to create a more powerful organization. But criticism of the merger proposal grew as vocal dissidents expressed concerns that the research-orientated OSA might be threatened by SPIE and its focus on applied research (see Nature 398, 547; 1999).

The OSA voted against the merger by 51 per cent (2,551 votes) to 49 per cent $(2,420$ votes). A two-thirds majority of voting members was needed to approve the merger.

"The members have spoken," said Anthony E. Siegman, OSA's president and a leading proponent of the merger. "In their view, a merger of OSA and SPIE is not in the best interests of the society at this time."

Daniel V. F. James, a theoretical physicist at Los Alamos National Laboratory in New Mexico and a critic of the merger proposal, said of the vote: "We are happy; it was the correct decision." 